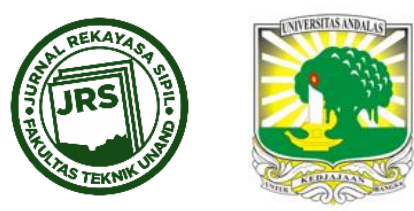

\title{
PENELAAHAN KUALITAS WORKMANSHIP PEKERJAAN KOMPONEN ARSITEKTUR PADA KONSTRUKSI GEDUNG DAN PENGENDALIANNYA BERDASARKAN KONSEP DMAIC
}

\author{
MEIFRINALDI \\ Kelompok Keahlian Manajemen dan Rekayasa Konstruksi, Fakultas Teknik Sipil dan Lingkungan, ITB \\ (هmeifrinaldi@gmail.com)
}

Naskah diterima : 16 Maret 2019. Disetujui: 20 Mei 2019. Diterbitkan : 24 Mei 2019

\begin{abstract}
ABSTRAK
Keberhasilan suatu proyek konstruksi dapat diukur dengan penilaian atas biaya, mutu/kualitas dan waktunya. Dari aspek - aspek yang ada pada pekerjaan konstruksi gedung, pekerjaan arsitektur merupakan pekerjaan dengan komponen-komponen yang dapat dilihat secara kasat mata, sehingga pekerjaan arsitektur cenderung menjadi sumber utama keluhan dan ketidakpuasan pihak owner (Pheng dan Hui, 2004). Penelitian yang dilakukan oleh Ellizar (2011) terhadap 2 proyek konstruksi yang dilakukan oleh 2 kontraktor bersertifikasi ISO, menemukan bahwa tingkat kualitas untuk pekerjaan arsitektur masih cenderung rendah, perlu dilakukan perbaikan - perbaikan untuk meningkatkan hal tersebut. Berangkat dari hal tersebut, pada penelitian ini dilakukan penelaahan dari sisi workmanship untuk pekerjaan komponen internal finishes (keramik lantai, dinding bagian dalam, plafond, pintu dan jendela) pada kontraktor menggunakan bantuan pendekatan DMAIC (Define - Measure - Analyze - Improve - Control) sebagai kerangka acuan dalam melakukan penelaahan. Penelitian ini mengambil studi kasus pada pembangunan Asrama Mahasiswa Kampus ITB Jatinangor. Berdasarkan hasil kajian dan perbandingan literatur, identifikasi cacat dan pengukurannya ditinjau berdasarkan standar kualitas workmanship yang dimiliki oleh Singapura, CONQUAS (Construction Quality Asessment System). Standar ini dikeluarkan oleh Building Construction Authority of Singapore. Selanjutnya proses perhitungan cacat dilakukan menggunakan cascading pada pareto serta bantuan fishbone diagram untuk mencari akar permasalahannya. Observasi dan interview dengan mandor di lapangan juga dilakukan untuk mengidentifikasi proses kerja yang dilakukan, standar yang digunakan dan permasalahan yang dihadapi. Dari hasil penelitian yang dilakukan telah disusun sebuah kerangka pengendalian workmanship untuk komponen arsitektur, serta teridentifikasi bahwa kondisi pekerja yang bekerja tidak mengikuti peraturan ataupun standar yang sudah dimiliki oleh kontraktor menjadi penyeb utama rendahnya kualitas workmanship untuk studi kasus pembangunan Asrama Mahasiswa Kampus ITB Jatinangor. Telah diidentifikasi pula perbaikan - perbaikan apa saja yang dapat dilakukan dalam rangka meningkatkan kualitas workmanship untuk pekerjaan komponen internal finishes.
\end{abstract}

Kata kunci : DMAIC, workmanship, CONQUAS, kerangka pengendalian 


\section{PENDAhUlUan}

Keberhasilan suatu proyek konstruksi dapat diukur dengan penilaian atas biaya, mutu/kualitas dan waktunya. Dari pernyataan tersebut dapat dilihat bahwa mutu/kualitas adalah salah satu kunci atas dinilai berhasilnya suatu konstruksi. Dari berbagai aspek utama dalam pekerjaan konstruksi gedung, pekerjaan arsitektur merupakan pekerjaan dengan komponen-komponen yang dapat dilihat secara kasat mata, sehingga pekerjaan arsitektur cenderung menjadi sumber utama keluhan dan ketidakpuasan pihak owner (Pheng dan Hui, 2004). Ketidakpuasan pihak owner disebabkan karena cacat/defect pada pekerjaan komponen arsitektur konstruksi gedung tersebut. Cacat/defect pada proyek konstruksi adalah sesuatu hal yang tidak memenuhi spesifikasi dari pihak owner (Latief, Utami, 2009).

Penelitian yang dilakukan oleh Ellizar (2011) terhadap 2 proyek konstruksi yang dilakukan oleh 2 kontraktor bersertifikasi ISO, menemukan bahwa tingkat kualitas untuk pekerjaan arsitektur masih cenderung rendah (masih terdapat banyak cacat), perlu dilakukan perbaikan - perbaikan untuk meningkatkan hal tersebut. Aspek penting dalam usaha untuk mengurangi cacat adalah dengan mengendalikan workmanship. Rendahnya tingkat workmanship pada bagian arsitektur khususnya di Indonesia umumnya dikaitkan dengan tidak tersedianya peraturan atau standar pekerjaan konstruksi yang jelas maupun tenaga kerja yang tidak mengikuti standar pekerjaan yang sudah ditetapkan sehingga menghasilkan ketidaksesuaian pekerjaan.

Penelitian oleh BRE Advisory Service yang dilakukan berdasarkan pemasukan sejumlah 862 database, terdiri dari 303 data yang berhubungan dengan perumahan dan 559 untuk konstruksi non perumahan (Watt, 1999). Housing Association Property Mutual (2004) memiliki analisis data yang sama berdasarkan audit dari sekitar 31000 tempat tinggal. Dari analisis data tersebut teridentifikasi potensi cacat umum untuk 6 elemen tertentu dari suatu konstruksi yaitu pondasi, lantai tanah, dinding pasangan bata eksternal, atap, serta lantai dan dinding pemisah. Diketahui pula bahwa efek cacat pada komponen arsitektur memiliki pengaruh yang signifikan terhadap performa dan ketahanan bangunan.

Saat ini, metode pengendalian kualitas produk yang sedang berkembang dan merupakan target pencapaian kualitas dengan pengukuran yang paling ketat adalah Six Sigma (6-sigma). Sasaran kinerjanya adalah kapabilitas produk dan proses dengan 3,4 DPMO (Defects Per Million Opportunities) atau 99,99966 persen produk bebas cacat (Gaspersz,2006). Ide dari metode pengendalian kualitas berbasiskan statistik ini adalah dengan meminimalisir variabilitas yang mungkin akan muncul dalam menghasilkan sebuah produk, sehingga produk yang dihasilkan nantinya akan berada pada rentang kendali yang sudah direncanakan.

Beberapa hal yang menjadi rumusan masalah dalam penelitian ini seperti komponen arsitektur merupakan komponen yang paling mudah secara kasat mata dilihat kondisi cacatnya. Cacat pada komponen arsitektur dapat berefek pada kinerja dari bangunan. Tingkat pengendalian kualitas workmanship di Indonesia masih rendah. Sertifikasi ISO belum dapat menjadi jaminan tingkat pengendalian kualitas workmanship yang baik. Di Australia, Love dkk (2000) menemukan bahwa sertifikasi ISO dilakukan terutama untuk tujuan pemasaran dan untuk menjadi pertimbangan dalam kontrak pemerintah, hal ini juga tidak jauh berbeda dengan yang terjadi di Indonesia. Kerangka pengendalian kualitas workmanship dibutuhkan dalam rangka usaha memberikan kontribusi pada perbaikan kualitas workmanship khususnya untuk komponen arsitektur di Indonesia. 


\section{PENDEKATAN PENELITIAN}

Penelitian ini dirancang sebagai studi untuk melakukan penelaahan kualitas workmanship pekerjaan komponen arsitektur pada konstruksi gedung dan pengendaliannya berdasarkan konsep DMAIC. Dengan menggunakan pendekatan secara kuantitatif dan kualitatif, maka pengambilan data dilakukan dengan cara pengamatan langsung ke lapangan, dilanjutkan dengan pengambilan data primer berupa metode kerja, kualitas pekerjaan, dan pengendalian kualitas yang diterapkan oleh kontraktor.

Sampling dilakukan untuk komponen arsitektur pada bagian lantai, dinding bagian dalam, langit - langit, pintu dan jendela Pada proyek pembangunan asrama mahasiswa di kampus ITB Jatinangor yang dilaksanakan oleh kontraktor grade 7 yang bersertifikat ISO. Perhitungan DPMO dilakukan dan kemudian dikonversikan kepada nilai sigma yang dicapai oleh proyek gedung tersebut.

Pada bagian awal penelitian terlebih dahulu dilakukan kajian literatur mengenai berbagai standar workmanship yang ada digunakan diberbagai negara. Dari hasil kajian tersebut dipilih CONQUAS yang dikeluarkan oleh Building Construction Authority Singapura karena memiliki tingkat kesesuaian yang cukup baik di Indonesia.

\section{INSTRUMEN PENELITIAN}

Instrumen yang digunakan dalam penelitian ini adalah pengumpulan data-data cacat langsung ke lapangan (konstruksi bangunan gedung) dan interview/wawancara kepada pihak yang terlibat dalam konstruksi gedung yang diamati. Pengamatan langsung pada penelitian ini dimaksudkan untuk mengumpulkan data mengenai cacat yang sering terjadi serta penyebab dari cacat tersebut. Pemeriksaan cacat difokuskan pada pekerjaan komponen arsitektur seperti pekerjaan lantai, dinding bagian dalam, plafond, pintu dan jendela dan didasarkan pada standar pemeriksaan cacat yang dimiliki oleh CONQUAS. Pengamatan akan dilakukan secara langsung, dimana cacat yang ditemukan akan dicatat dan didokumentasikan.

Proses selanjutnya adalah interview, terdapat 2 tujuan utama dari interview ini yaitu untuk mengetahui metoda pelaksanaan untuk pekerjaan arsitektur yang diamati pada penelitian ini serta mengumpulkan seluruh informasi yang berkaitan dengan pekerjaan arsitektur yang diamati. Hasil dari Interview/Wawancara ini nantinya akan digunakan dalam melakukan penelaahan terhadap pengendalian kualitas pekerjaan komponen arsitektur pada kontraktor konstruksi gedung menggunakan pendekatan DMAIC. Interview/Wawancara khususnya dapat digunakan sebagai sumber informasi pada fase Improve. Target sebagai narasumber dari Interview/Wawancara ini adalah mandor untuk masing - masing pekerjaan arsitektur yang sudah dipilih dalam penelitian ini.

\section{STUDI KASUS}

Penelitian ini mengambil studi kasus pada proyek pembangunan asrama mahasiswa kampus ITB Jatinangor. Pemilihan dilakukan berdasarkan sertifikasi ISO yang sudah dimiliki oleh kontraktor yang mengerjakan, serta bentuk bangunan yang bertipe modular. Proyek pembangunan asrama mahasiswa kampus ITB merupakan proyek pembangunan rumah susun sederhana lima lantai yang terdiri atas 2 bangunan I yang sejajar. Bangunan ini diperuntukkan sebagai hunian: tipe 24 sebanyak 96 unit per Tower, dan tipe diffable(Untuk penyandang cacat) sebanyak 8 unit pada Tower 2 . 
Lingkup pekerjaan dari proyek ini adalah pekerjaan sub struktur, pekerjaan struktur, arsitektur, mekanikal, elektrikal serta plumbing. Secara umum tahapan kerja pembangunan asrama mahasiswa kampus ITB, dikelompokkan menjadi beberapa bagian sebagai berikut :Perencanaan lay out lapangan ; Persiapan; Pekerjaan sub struktur; Perencanaan tahapan struktur dan precast; Pekerjaan arsitektur dan MEP; Penyusunan schedule kerja.

Dalam proyek pembangunan asrama mahasiswa kampus ITB, kontraktor yang digunakan adalah WIKA Realty. PT Wijaya Karya Realty (WIKA Realty) memiliki fokus pada pengembangan bisnis realty dan property yang juga meliputi layanan konsultasi, perencanaan, layanan konstruksi dan pembukaan lahan. WIKA Realty telah membangun beberapa perumahan sejak tahun 1985 . WIKA Realty telah meraih beberapa penghargaan untuk kesuksesannya dalam pengembangan bidang realty baik dalam skala regional maupun nasional, seperti: The Winner of Ecologically Environment Real Estate in West Java pada tahun 1993, The Winner of Enchantment Tour in Bekasi Region pada tahun 1995, The Winner of Wirastana Adistana Environmental Design of REI National Grade 1995, The Winner of Nusa Adikualita, National Application Award pada tahun 1997, The Winner of Environmental Garden Estate in Bandung Region pada tahun 1997. Untuk memastikan pengembangan kualitas dan kepuasan konsumen, WIKA REALTY telah melaksanakan Manajemen Kualitas ISO 9001 (berdasarkan sertifikasi ISO 9001 Lloyd Register Quality Assurance pada tahun 1995 dan selalu diperbaharui sampai sekarang) di setiap produknya, hal ini merupakan jawaban dari setiap tantangan dalam pemenuhan kebutuhan konsumen yang dibuktikan melalui perolehan peningkatan pertumbuhan

\section{KERANGKA PENGENDALIAN WORKMANSHIP UNTUK PENELAAHAN}

Kerangka pengendalian workmanship pekerjaan komponen arsitektur pada konstruksi gedung berdasarkan konsep DMAIC dibuat untuk memberikan gambaran umum mengenai langkah - langkah pengendalian pekerjaan komponen arsitektur yang dapat dilakukan oleh kontraktor. Langkah - langkah pengendalian pekerjaan komponen arsitektur tersebut akan disusun berdasarkan prinsip DMAIC dalam six sigma. Dalam kerangka ini akan coba dijabarkan mengenai langkah penjaminan mutu apa saja yang dapat dilakukan untuk masing - masing tahap, alat bantu yang dapat digunakan, hingga acuan standar kepuasan pelanggan atau target mutu yang ingin dicapai. Dengan adanya kerangka pengendalian workmanship pekerjaan komponen arsitektur pada konstruksi gedung berdasarkan konsep DMAIC, proses penelaahan yang akan dilakukan pada tahap selanjutnya akan mengacu pada kerangka yang sudah didefinisikan. Kerangka ini dikembangkan dalam bentuk siklus perbaikan berdasarkan konsep Six sigma yang terdiri atas 5 fase yaitu: Define, Measure, Analyze, Improve, Control. Masing - masing fase dalam siklus DMAIC akan menjadi poin penting dalam kerangka pengendalian workmanship pekerjaan komponen arsitektur. Dalam tiap fase akan dijabarkan langkah - langkah pengendalian apa saja yang dapat dilakukan secara sistematis dan berurutan sesuai dengan fungsi masing - masing fase.

\subsection{Tahap Define}

Pada tahap define akan didefinisikan secara detail proses pekerjaan yang akan dilakukan. Dalam penelitian ini proses pekerjaan yang akan ditinjau secara detail adalah pekerjaan lantai, dinding bagian dalam, plafond, jendela dan pintu. Selanjutnya setelah proses detail dari masing - masing pekerjaan diketahui, akan dilakukan analisis mengenai siapa saja pelanggan untuk masing - masing komponen pekerjaan, baik internal maupun eksternal. Terakhir akan didefinisikan juga tingkat kepuasan pelanggan yang ingin dicapai, dijabarkan dalam sebuah standar yang akan digunakan sebagai acuan dasar. 
Untuk proses penelaahan yang dilakukan diketahui bahwa secara umum, standar pengendalian dan pelaksanaan pekerjaan internal finishes komponen lantai, dinding bagian dalam, plafond pintu dan jendela yang dimiliki oleh kontraktor sudah baik. Untuk masing masing komponen sudah diberikan jenis kontrol yang harus dilakukan dan pada tahapan mana kontrol tersebut dilaksanakan.

\subsection{Tahap Measure}

Pada tahap Measure performa proses kerja dan produk yang dihasilkan dievaluasi dan diukur menggunakan pengukuran performa berdasarkan prinsip six sigma. Faktor utama untuk mengembangkan sistem pengukuran performa secara sistematis adalah dengan mengetahui indikator performa dan CTQ (Critical to Quality). CTQ dijabarkan berdasarkan kebutuhan dari pelanggan yang sudah dinyatakan dalam standar yang digunkan sebagai acuan. CTQ adalah seluruh karakteristik kunci pada proses maupun produk yang dihasilkan dan merupakan sesuatu yang dapat diukur. Untuk penelitian ini CTQ yang sudah didefinisikan dapat dilihat seperti pada Tabel 1.

Tabel 1. Critical to Quality komponen internal finishes

\begin{tabular}{|c|c|}
\hline Komponen & CTQ \\
\hline Pekerjaan keramik lantai & $\begin{array}{l}\text { 1. Kondisi material baik } \\
\text { 2. Kondisi peralatan baik } \\
\text { 3. Area dan lokasi pekerjaan steril } \\
\text { 4. Perencanaan pemasangan } \\
\text { 5. Kondisi elevasi keramik } \\
\text { 6. Tidak terdapat cacat finishing, kerataan permukaan, keretakan, } \\
\text { sambungan dan kehampaan } \\
\text { 7. Kebersihan dan kerapian terjaga dengan baik } \\
\text { 8. Area dan lokasi setelah pemasangan steril selama } 1 \text { hari }\end{array}$ \\
\hline $\begin{array}{l}\text { Pekerjaan dinding bagian } \\
\text { dalam }\end{array}$ & $\begin{array}{l}\text { 1. Kondisi material baik } \\
\text { 2. Kondisi peralatan baik } \\
\text { 3. Area dan lokasi pekerjaan steril } \\
\text { 4. Koordinasi dengan pekerjaan mekanikal dan elektrikal } \\
\text { 5. Tidak terdapat cacat finishing, kerataan permukaan, keretakan, } \\
\text { sambungan dan kehampaan } \\
\text { 6. Kebersihan dan kerapian terjaga dengan baik }\end{array}$ \\
\hline Pekerjaan plafond & $\begin{array}{l}\text { 1. Kondisi material baik } \\
\text { 2. Kondisi peralatan baik } \\
\text { 3. Area dan lokasi pekerjaan steril } \\
\text { 4. Koordinasi dengan pekerjaan mekanikal dan elektrikal } \\
\text { 5. Tidak terdapat cacat finishing, kerataan permukaan, keretakan, } \\
\text { sambungan dan kekasaran } \\
\text { 6. Kebersihan dan kerapian terjaga dengan baik }\end{array}$ \\
\hline $\begin{array}{lll}\text { Pekerjaan pintu } & \text { dan } \\
\text { jendela } & & \\
\end{array}$ & $\begin{array}{l}\text { 1. Kondisi material baik } \\
\text { 2. Kondisi peralatan baik } \\
\text { 3. Area dan lokasi pekerjaan steril } \\
\text { 4. Tidak terdapat cacat pada sambungan dan kerataan } \\
\text { 5. Aksesoris pintu dan jendela lengkap } \\
\text { 6. Jendela dan pintu dapat dibuka, ditutup dan dikunci dengan baik } \\
\text { 7. } \\
\text { Kebersihan dan kerapian terjaga dengan baik }\end{array}$ \\
\hline
\end{tabular}

Setelah CTQ dan target CTQ didefinisikan, selanjutnya perlu dilakukan pengumpulan data untuk mengukur performa dari proses kerja atau produk yang dihasilkan. Penentuan cacat/defect terhadap komponen - komponen arsitektur yang menjadi objek dalam penelitian ini dilakukan dengan cara mengamati langsung cacat - cacat yang ada pada komponen tersebut, kemudian mencatatkannya dalam sebuah lembar pengamatan, untuk 

dan Pengendaliannya Berdasarkan Konsep DMAIC

selanjutnya dihitung nilai DPMO (Defect Per Milion Opportunities) masing - masing komponen. Dari nilai DPMO tersebut akan dibuat sebuah diagram pareto untuk mengetahui jenis cacat apa yang paling berpengaruh terhadap komponen tersebut, kemudian dilakukan cascading untuk mengetahui permasalahan apa yang menyebabkan jenis cacat yang paling berpengaruh tersebut. Nilai DPMO dihitung menggunakan rumus:

DPMO $=\left(\frac{\text { No.of defect }}{\text { No.of opportunities } x \text { No.of units }}\right) \times 1,000,000$.

No of defect : Jumlah cacat yang teramati dalam pengamatan langsung

No of units : Jumlah total unit yang diamati

No of opportunities : Jumlah kemungkinan cacat yang dapat timbul untuk satu set pengamatan
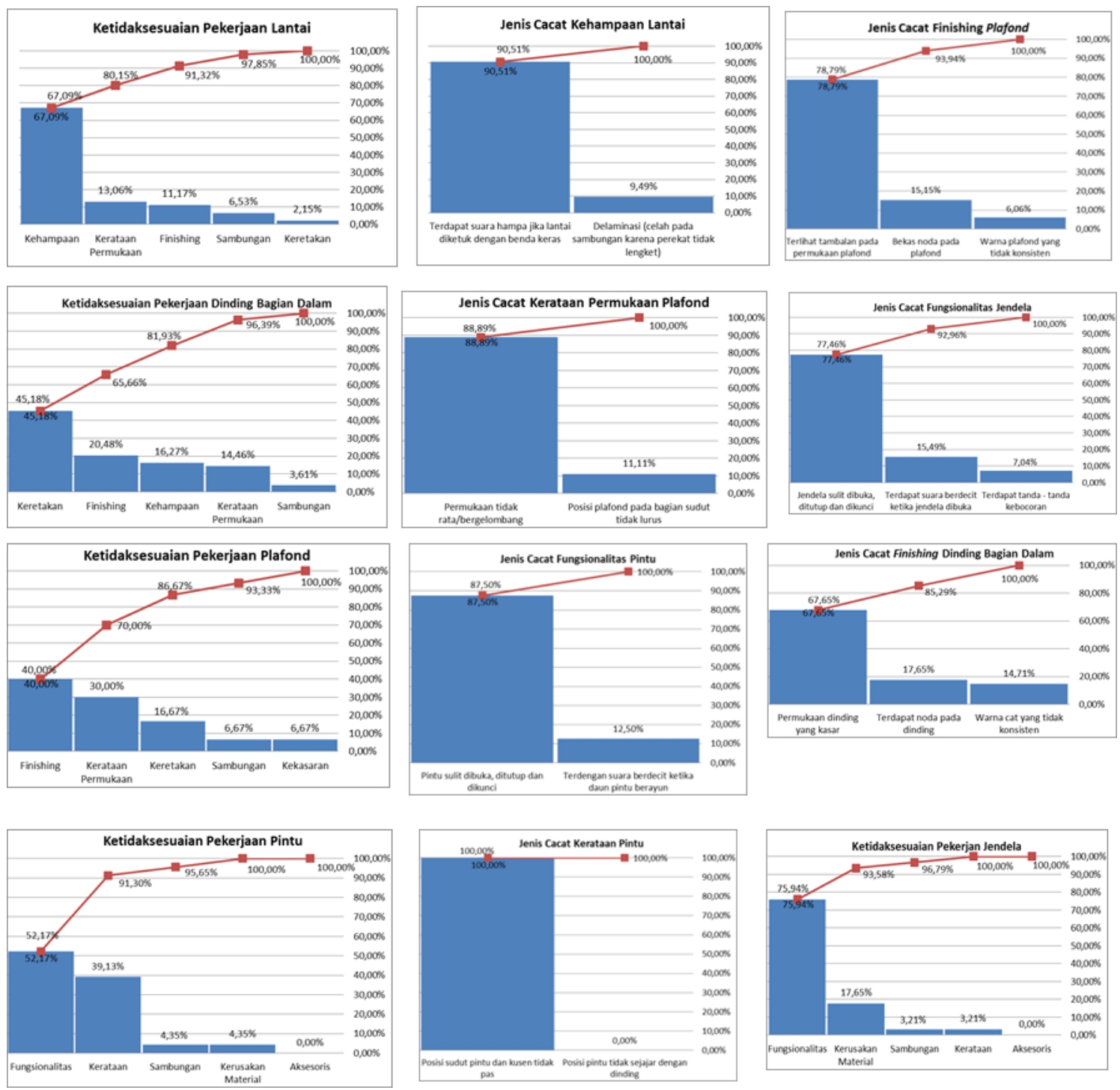

Gambar 1. Perhitungan DPMO dan cacat yang berpengaruh

Perhitungan akan dimulai dari jenis cacat yang paling umum untuk masing - masing komponen. Dari jenis cacat umum tersebut kemudian akan dilihat persentase DPMO nya dari persentase DPMO total keseluruhan pada komponen tersebut. Prinsip pareto digunakan untuk melakukan cascading ini, jenis cacat umum yang memiliki persentase 
DPMO diatas 20\% dari DPMO total akan diteliti lebih lanjut. Jenis cacat umum yang diteliti lebih lanjut akan dikembangkan menjadi jenis - jenis cacat yang lebih khusus dan kemudian kembali digunakan prinsip pareto untuk memperoleh jenis cacat yang akan menjadi fokus perbaikan untuk komponen tersebut. Untuk hasil perhitungan DPMO dan jenis cacat apa saja yang berpengaruh pada masing - masing komponen pada penelitian ini dapat dilihat pada Gambar 1.

\subsection{Tahap Analyze}

Pada tahap analyze akan diidentifikasi kapan, dimana dan mengapa cacat terjadi, termasuk potensi terjadinya cacat. Identifikasi ini dapat dilakukan dengan mencari akar penyebab dari permasalahan tersebut timbul. Cause and effect analysis dapat digunakan untuk membantu mencari akar penyebab dari permasalahan yang ada. Fishbone Diagram dapat digunakan sebagai salah satu alat bantu dalam melakukan Cause and effect analysis. Dengan bantuan fishbone diagram kita dapat mencari faktor - faktor yang memiliki pengaruh paling besar terhadap terjadinya cacat. Pengetahuan dan pengalaman dari engineer, pengawas, serta anggota tim pada proyek dapat digunakan sebagai informasi tambahan untuk melakukan cause and effect analysis.

Proyek konstruksi yang umumnya terdiri atas banyak proses dan aktifitas pendahulu memerlukan identifikasi yang komprehensif dalam menemukan akar penyebab permasalahan. Koordinasi dari proses dan aktifitas yang berkaitan perlu diperhatikan dan perlu diatur interaksinya untuk mencapai hasil akhir yang diinginkan. Kurangnya koordinasi yang efektif dari beberapa aktifitas dan proses yang berbeda umumnya merupakan penyebab utama dari cacat yang timbul. Terdapat faktor lain yang juga berpengaruh terhadap kondisi cacat pada suatu pekerjaan seperti akses masuk ke dalam site, peralatan, logistik, sumber daya, dan kompetensi dari pekerja. Selain itu faktor lain yang juga tidak kalah pentingnya untuk diperhatikan adalah kondisi cuaca. Kondisi cuaca dapat menjadi penghambat pekerjaan konstruksi, kondisi cuaca yang jelek (kelembaban tinggi, panas tinggi,dll) juga dapat menjadi pemicu timbulnya cacat. Seluruh faktor - faktor ini akan ditinjau dalam fase analyze untuk mencari akar penyebab permasalahan cacat yang ada. Jenis cacat yang berpengaruh pada masing - masing komponen untuk penelitian ini dapat dilihat pada Tabel 2.

Tabel 2. Jenis cacat dan penyebabnya pada komponen arsitektur

\begin{tabular}{ll}
\hline $\begin{array}{l}\text { Komponen } \\
\text { Arsitektur }\end{array}$ & Jenis cacat dan Penyebabnya \\
\hline Lantai & $\begin{array}{l}\text { Jenis cacat: Terdapat suara hampa jika lantai diketuk dengan benda keras. } \\
\text { Penyebab cacat: Pekerja hanya bekerja dengan pengalaman dan tidak mengikuti } \\
\text { standar pengerjaan yang sudah dibuat oleh kontraktor ; Tidak adanya tindakan } \\
\text { pengendalian yang dilakukan kontraktor untuk mencegah timbulnya cacat } \\
\text { tersebut. }\end{array}$ \\
\hline $\begin{array}{l}\text { Dinding } \\
\text { bagian dalam }\end{array}$ & $\begin{array}{l}\text { Jenis cacat: Terlihat retak pada bagian dinding } \\
\text { Penyebab cacat: Kondisi pengendalian dan perencanaan pekerjaan yang kurang } \\
\text { baik dari kontraktor; Tidak dilakukan pengecekan kembali oleh kontraktor untuk } \\
\text { dinding - dinding yang mengalami perbaikan akibat reworks instalasi mekanikal } \\
\text { maupun elektrikal. }\end{array}$ \\
& $\begin{array}{l}\text { Jenis cacat: Permukaan dinding yang kasar } \\
\text { Penyebab cacat: Pekerja tidak mengikuti acuan/ tata cara pelaksanaan pekerjaan } \\
\text { yang sudah dimiliki oleh kontraktor; Proses quality assurance dari kontraktor juga } \\
\text { memberikan kontribusi terhadap terjadinya cacat. }\end{array}$ \\
\hline Plafond & Jenis cacat: Terlihat tambalan pada permukaan plafond \\
\hline
\end{tabular}




\begin{tabular}{ll}
\hline $\begin{array}{l}\text { Komponen } \\
\text { Arsitektur }\end{array}$ & Jenis cacat dan Penyebabnya \\
\hline & $\begin{array}{l}\text { Penyebab cacat: Pekerja tidak mengikuti acuan/tata cara pelaksanaan pekerjaan } \\
\text { yang sudah dimiliki oleh kontraktor; Kebersihan dan kerapian dari pekerjaan } \\
\text { yang dilakukan kurang diperhatikan; Proses quality assurance dari kontraktor } \\
\text { yang kurang baik }\end{array}$ \\
& $\begin{array}{l}\text { Jenis cacat: Permukaan plafond tidak rata. } \\
\text { Penyebab cacat: Pekerja tidak mengikuti acuan/ tata cara pelaksanaan pekerjaan } \\
\text { yang sudah dimiliki oleh kontraktor; Pekerja kurang memperhatikan kelurusan } \\
\text { pada bagian ujung - ujung plafond dalam pengerjaannya }\end{array}$ \\
& Jenis cacat: Pintu sulit dibuka, ditutup dan dikunci \\
& Penyebab cacat: Pekerja tidak mengikuti acuan/ tata cara pelaksanaan pekerjaan \\
& yang sudah dimiliki oleh kontraktor; Pekerja kurang memperhatikan jarak \\
& minimum antara lantai dan pintu serta kebersihan pada bagian bawah pintu. \\
& Jenis cacat: Posisi sudut pintu dan kusen tidak pas. \\
& $\begin{array}{l}\text { Penyebab cacat: Pekerja tidak mengikuti acuan/tata cara pelaksanaan pekerjaan } \\
\text { yang sudah dimiliki oleh kontraktor; Proses quality assurance kontraktor yang } \\
\text { tidak mengakomodir pengendalian terhadap cacat tersebut. }\end{array}$ \\
\hline Jenis cacat: Jendela sulit dibuka, ditutup dan dikunci \\
& $\begin{array}{l}\text { Penyebab cacat: Pekerja tidak mengikuti acuan/ tata cara pelaksanaan pekerjaan } \\
\text { yang sudah dimiliki oleh kontraktor; Proses quality assurance kontraktor yang } \\
\text { tidak mengakomodir pengendalian terhadap kondisi jendela yang sulit dibuka, } \\
\text { ditutup dan dikunci }\end{array}$ \\
\hline
\end{tabular}

\subsection{Tahap Improve}

Pada tahap improve akan dicoba mengeliminasi cacat yang sudah diidentifikasi dari fase analyze. Proses eliminasi cacat dapat dimulai dari pengaturan aktifitas dan proses yang ada agar dapat berjalan dengan baik. Beberapa hal yang dapat dilakukan berkaitan dengan pengaturan aktifitas dan proses yang ada seperti (Tehrani, 2010):

- Mengeliminasi gap antara proses dan/atau aktifitas yang berbeda

- Meminimalkan pengaruh jika terjadi kegagalan aktifitas dan/atau proses yang menjadi preseden aktifitas dan/atau proses lainnya

- Meningkatkan operasi secara keseluruhan dan megeliminasi kegagalan secepat mungkin untuk mencegah terjadinya efek kegagalan berantai

Seperti yang sudah disebutkan diatas, pada tahap improve akan dicoba mengeliminasi akar penyebab permasalahan cacat berdasarkan informasi dan pengalaman yang sudah diperoleh pada fase sebelumnya. Proses perbaikan yang dapat dilakukan seperti peningkatan kualitas alat, pembelian material dengan kualitas yang lebih baik, serta peningkatan kompetensi pekerja. Meskipun demikian, seluruh proses perbaikan yang akan dilakukan perlu mempertimbangkan aspek finansial dari proyek itu sendiri. Proses peningkatan yang dilakukan akan memerlukan biaya yang tidak sedikit, pengeluaran ini akan menjadi sia - sia jika peningkatan yang dihasilkan tidak mempengaruhi proses bisnis dan keuntungan dalam jangka menengah hingga jangka panjang.

Secara efektif proses perbaikan harus dilaksanakan secara bertahap, dimulai dari mengeliminasi permasalahan utama yang menyebabkan cacat paling banyak. Setelah dilakukan proses perbaikan, maka proses perbaikan tersebut akan dievaluasi dan dilihat signifikansinya terhadap pengurangan cacat yang timbul. Jika cacat yang timbul berkurang secara signifikan maka proses perbaikan yang dilakukan sudah benar dan dapat terus 
ditingkatkan. Jika cacat yang timbul tidak berkurang secara signifikan, perlu dilakukan kembali analisis terhadap penyebab cacat serta analisis terhadap proses perbaikan yang dilakukan. Jenis perbaikan yang dapat dilakukan pada studi kasus penelitian ini dapat dilihat pada Tabel 3.

Tabel 3. Langkah peningkatan yang dapat dilakukan kontraktor

\begin{tabular}{|c|c|}
\hline $\begin{array}{l}\text { Komponen } \\
\text { Arsitektur }\end{array}$ & Langkah peningkatan yang dapat dilakukan \\
\hline Lantai & $\begin{array}{l}\text { - Memastikan aturan dan tata cara pekerjaan yang sudah ada dilaksanakan } \\
\text { dengan baik dan benar untuk pekerjaan lantai. } \\
\text { - Pemeriksaan yang dilakukan mencakup pemeriksaan terhadap kondisi lantai } \\
\text { yang dapat menimbulkan suara hampa jika diketuk dengan benda keras } \\
\text { - Detail teknik pengerjaan yang dilakukan memperhatikan tata cara meratakan } \\
\text { adukan keramik, kondisi kekentalan adukan, serta teknik pemberian nat pada } \\
\text { keramik. }\end{array}$ \\
\hline $\begin{array}{l}\text { Dinding } \\
\text { bagian dalam }\end{array}$ & $\begin{array}{l}\text { - Memperbaiki sistem pengendalian mutu pekerjaan dinding bagian dalam yang } \\
\text { dimiliki serta selalu diselaraskan pemeriksaannya dengan perubahan - } \\
\text { perubahan yang dapat mempengaruhi kondisi pekerjaan yang dikendalikan. } \\
\text { - } \\
\text { Pemberian pemahaman kepada pekerja mengenai tata cara pengerjaan dan } \\
\text { syarat terselesaikannya suatu pekerjaan, sehingga pekerja akan bertanggung } \\
\text { jawab penuh terhadap pekerjaannya hingga pekerjaan tersebut benar-benar } \\
\text { selesai. } \\
\text { - Pengendalian terhadap pekerjaan lain yang dilakukan pada unit yang sama } \\
\text { setelah pekerjaan dinding bagian dalam selesai harus diawasi dengan baik dan } \\
\text { didesain tidak akan mengganggu hasil pekerjaan dinding bagian dalam yang } \\
\text { sudah selesai diperiksa dan diperbaiki. } \\
\text { - Detail teknik pengerjaan yang dilakukan memperhatikan proses pengeringan } \\
\text { plesteran dan acian. Waktu normal pengeringan diusahakan berkisar } 2 \\
\text { minggu, untuk perbaikan jika terjadi kesalahan marking instalasi dapat diberi } \\
\text { jeda waktu berkisar 1 minggu. } \\
\text { Detail teknik pengerjaan yang dilakukan memperhatikan tata cara melakukan } \\
\text { plesteran dan pengecatan agar hasil pengecatan dan plesteran rata. }\end{array}$ \\
\hline Plafond & $\begin{array}{l}\text { Memastikan aturan dan tata cara pekerjaan yang sudah ada dilaksanakan } \\
\text { dengan baik dan benar untuk pekerjaan plafond. } \\
\text { - Pengendalian terhadap reworks pekerjaan lain yang harus diawasi dengan baik } \\
\text { dan didesain tidak akan mengganggu hasil pekerjaan plafond yang sudah } \\
\text { selesai diperiksa dan diperbaiki. } \\
\text { - Detail teknik pengerjaan yang dilakukan memperhatikan tingkat kekeringan } \\
\text { dari bahan tambalan, proses pembersihan bagian yag ingin ditambal, serta } \\
\text { jenis bahan penambal harus sama dengan bahan dasar plafond. } \\
\text { - Detail teknik pengerjaan yang dilakukan memperhatikan pengukuran } \\
\text { kerataan pemasangan plafond serta teknik pelapisan plafond agar permukaan } \\
\text { rata. }\end{array}$ \\
\hline Pintu & $\begin{array}{l}\text { - Memastikan aturan dan tata cara pekerjaan yang sudah ada dilaksanakan } \\
\text { dengan baik dan benar, } \\
\text { - Proses pengendalian pekerjaan dan pemeriksaan hasil pekerjaan juga perlu } \\
\text { diperbaiki dengan memperhatikan aspek - aspek fungsionalitas dan kerataan } \\
\text { pada pintu } \\
\text { - Detail teknik pengerjaan yang dilakukan memperhatikan pemeriksaan } \\
\text { terhadap kondisi pintu pada saat dibuka, ditutup, dan dikunci, kebersihan pada } \\
\text { bagian bawah pintu, serta kelurusan pemasangan engsel. } \\
\text { - Detail teknik pengerjaan yang dilakukan memperhatikan ketepatan } \\
\text { pengukuran kusen dan pintu serta posisi untuk dudukan engsel pintu }\end{array}$ \\
\hline Jendela & $\begin{array}{l}\text { Memastikan aturan dan tata cara pekerjaan yang sudah ada dilaksanakan } \\
\text { dengan baik dan benar }\end{array}$ \\
\hline
\end{tabular}



dan Pengendaliannya Berdasarkan Konsep DMAIC

\begin{tabular}{ll}
\hline $\begin{array}{l}\text { Komponen } \\
\text { Arsitektur }\end{array}$ & Langkah peningkatan yang dapat dilakukan \\
\hline & $-\begin{array}{l}\text { Proses pengendalian pekerjaan dan pemeriksaan hasil pekerjaan juga perlu } \\
\text { diperbaiki dengan memperhatikan aspek - aspek fungsionalitas pada jendela. }\end{array}$ \\
- & $\begin{array}{l}\text { Detail teknik pengerjaan yang dilakukan memperhatikan pemeriksaan } \\
\text { terhadap kondisi jendela pada saat dibuka ditutup dan dikunci, serta kelurusan } \\
\text { pemasangan engsel. }\end{array}$ \\
\hline
\end{tabular}

\subsection{Tahap Control}

Tahap control berfungsi untuk memastikan keberlanjutan dan pengembangan perbaikan yang sudah dilakukan pada tahap improve. Pada tahap ini diperlukan pengumpulan data secara kontinu serta pengukuran performa proses dan produk. Beberapa hal yang perlu dilakukan pada tahap control adalah:

- Evaluasi perbaikan yang dilakukan serta memastikan perbaikan yang dilakukan sudah sesuai dengan yang direncanakan

- Pencegahan terulangnya kembali kegagalan yang sudah pernah dieliminasi

- Mengeksplorasi area - area yang berpotensi untuk perbaikan lebih lanjut.

Selain itu proses dokumentasi informasi dan pengalaman yang diperoleh selama proses perbaikan juga dilakukan pada tahap ini. Informasi dan pengalaman yang diperoleh tersebut kemudian dibagikan kepada anggota tim dan pengawas untuk memperoleh feedback. Pada proses control ini direkomendasikan untuk mengalokasikan beberapa orang untuk bertanggung jawab memonitor keseluruhan proyek yang berjalan termasuk perbaikan perbaikan yang dilakukan (Tehrani 2010). Tindakan kontrol untuk masing - masing tahap pada studi kasus penelitian ini dapat dilihat pada Tabel 4.

Tabel 4. Tindakan pada masing - masing tahap

\begin{tabular}{ll}
\hline $\begin{array}{c}\text { Metodologi six } \\
\text { sigma }\end{array}$ & Tindakan kontrol \\
\hline Tahap define & - Pendefinisian proses detail pekerjaan untuk masing - masing komponen \\
& - Penentuan karakteristik kualitas \\
& - Identifikasi ketidaksesuaian/cacat \\
& - Perincian pekerjaan komponen arsitektur secara detail \\
\hline Tahap measure & - Menetapkan sistem pengukuran dan standar yang digunakan \\
& - Pengembangan rencana pengumpulan data \\
& - Melakukan perbandingan terhadap data yang sudah dikumpulkan untuk \\
& mengetahui isu pada suatu pekerjaan \\
\hline Tahap analyze & - Mengidentifikasi variasi yang terjadi pada suatu pekerjaan \\
& - Menentukan prioritas perbaikan yang dapat dilakukan \\
& - Analisa faktor - faktor penyebab cacat dan variasi yang terjadi \\
\hline Tahap improve & - Penetapan rencana perbaikan \\
& - Pelatihan dan peningkatan kompetensi pihak - pihak yang terlibat terutama \\
& yang berkaitan langsung dengan proses kerja (tukang, supervisor,dll) \\
\hline Tahap control & - Rencana pengendalian kualitas \\
& - Implementasi pemahaman dan konsep mutu \\
& - Rencana pengembangan sistem dokumentasi dan pengamatan \\
\hline
\end{tabular}

\section{KESIMPULAN}

1. Dari hasil kajian terhadap literatur yang berkaitan dengan workmanship serta beberapa standar workmanship terkait yang sudah ada seperti CONQUAS, American Standards for Licensed Contractor, dan kemudian digabungkan dengan konsep DMAIC, telah 
diidentifikasi kerangka umum pengendalian workmanship pada pekerjaan internal finishes dalam bentuk Critical to Quality yang dapat dilihat pada Tabel 1.

2. Dari hasil penelaahan workmanship pada proyek pembangunan asrama mahasiswa ITB Jatinangor terdapat beberapa jenis cacat yang signifikan berada pada komponen internal finishes serta penyebab dari cacat tersebut seperti yang dapat dilihat pada Tabel 2. Secara umum berdasarkan hasil studi kasus yang dilakukan, diketahui bahwa kondisi pekerja yang bekerja tanpa mengikuti peraturan dan prosedur kerja yang sudah ada merupakan penyebab utama munculnya cacat pada komponen pekerjaan internal finishes.

3. Dari hasil penelaahan terhadap jenis - jenis cacat yang signifikan berpengaruh pada proyek pembangunan asrama mahasiswa ITB Jatinangor, terdapat beberapa perbaikan yang dapat dilakukan oleh kontraktor untuk meningkatkan kualitas workmanship pada komponen - komponen internal finishes seperti yang dapat dilihat pada Tabel 3.

4. Dari hasil perbaikan yang telah dilakukan terhadap jenis -jenis cacat yang signifikan berpengaruh pada proyek pembangunan asrama mahasiswa ITB Jatinangor, telah diidentifikasi tindakan - tindakan yang harus dilakukan untuk setiap tahapan, seperti yang dapat dilihat pada Tabel 4.

\section{DAFTAR PUSTAKA}

Andi, A., \& Chandra, H. P. (2005). Budaya Kualitas Pada Proyek Konstruksi. Bandung: Kelompok Keahlian Manajemen dan Rekayasa Konstruksi. Institut Teknologi Bandung.

Bregman, B. \& Klefsjo, B. (2005). The TQM Magazine. 17(1),19-34.

Building and Construction Authority. (2008). Conquas 21 : The BCA construction quality assessment system (7th ed). Singapore : BCA.

Building Research Establishment (BRE) (1988). Common defects in Low rise Traditional Housing. Digest 268. Garston : BRE.

Construction Quality Forum (CQF) (1997). CQF Database Analysis-Report 4, April 1997. Garston: CQF.

Davison, J.I. (2000). Workmanship and Rain Peneration of Masonry Walls. Atlantic Regional Station, Division of Building Research. National Research Council of Canada

Ellizar, E. (2011). Analisis Penerapan Metode Six Sigma Untuk Pengendalian Kualitas Pekerjaan Komponen Arsitektur Pada Konstruksi Gedung Di Indonesia (Tesis). Institut Teknologi Bandung.

Gaspersz, V. (2001). Total Quality Management. Jakarta: Gramedia Pustaka Utama.

Goetsch, D.L., \& Davis, S.B. (1994). Quality Management : Introduction to Total Quality Management for Production, Processing and Services. Pearson Pretice Hall.

Hurley, B. F. (1995). Age, gender, and muscular strength. Journals of Gerontology-Biological Sciences and Medical Sciences, 50, 41-44.

Karim, K., Marosszeky, M., Chung, H., Kumaraswamy, M., \& Low, S.P. (2000). A Comparative Study of ISO 9000 Quality Management System in the construction Industry: Australia, Hongkong and Singapore. Proceeding of 5th International Conference on ISO 9000 and TQM-Action 2000: Imperatives for Improvement, Singapore.

Krishnamoorthi, K.S. (2006). A first course in quakity engineering. New Jersey : Pearson education, inc.

Love, P.E.D., Li, H., Irani, Z., \& Faniran, O. (2000). Total Quality Management and The Learning Organisation: A Dialogue for Change in Construction. Construction Managements and Economics, 18, 321-331.

Pande, P. S., Neuman, R.P., \& Cavenaugh, R.R. (2005). The Six Sigma Way Team Fieldbook. New York: McGraw Hill.

Pheng, L. S., \& Hui, M. S. (2004). Implementing and applying Six Sigma in construction. Journal of construction engineering and management, $130(4), 482-489$.

Rumane, A.R. (2011). Quality Management in Construction Project. Taylor and Francis Group. 

dan Pengendaliannya Berdasarkan Konsep DMAIC

Stewart, R.A., \& Spencer, C. (2006). Delivering the promise: Six-Sigma as a Strategy for Process Improvement On Construction Projects. Proceeding of The ninth east Asia-Pacific Conference on Structural Engineering and Construction.

Tehrani, M.D, (2010). Performance Improvement in Construction Project Based on Six Sigma Principles (Thesis). University of Boras

Wah, L.S., Min, L.C., \& Ann, T.W. (1994). ISO 9000 In Construction. Singapore : Mc. Graw Hill Book Co.

Watt, D. S,. (1999). Building Pathology Principle and Practice. Blackwell Science.

Wood, B,. (2009). Building Maintenance. Wiley Blackwell.

Y. Latief, \& Utami, R. P.. (2009). Penerapan Pendekatan Metode Six Sigma Dalam Penjagaan Kualitas Pada Proyek Konstruksi. Makara Teknologi, 13(2), 67-72. 